\title{
Potential determinants of Clostridium spp. occurrence in Polish silage
}

\author{
Magdalena Goldsztejn, Tomasz Grenda ${ }^{\bowtie}$, Nina Kozieł, Magdalena Sapała, \\ Małgorzata Mazur, Zbigniew Sieradzki, Beata Król, Krzysztof Kwiatek \\ Department of Hygiene of Animal Feeding Stuffs \\ National Veterinary Research Institute, 24-100 Puławy, Poland \\ tomasz.grenda@piwet.pulawy.pl
}

Received: May 20, $2020 \quad$ Accepted: October 20, 2020

\begin{abstract}
Introduction: Silage quality deteriorates with Clostridium spp. contamination, and if consumed, such silage jeopardises herd health and productivity. Minimising its occurrence reduces economic and animal welfare risks. The study investigated the influence of environmental and technological determinants on the Clostridium genus' occurrence in silage. Material and Methods: Analyses were conducted on 305 silage samples directly collected from farms located in all Polish provinces. Cultures and isolates were evaluated phenotypically and examined for occurrence of Clostridium spp., particularly C. perfringens and C. botulinum using PCR techniques. The results were statistically analysed using the $\chi^{2}$ test for continuous and Student's $t$-test for non-continuous values. Results: The most influential effect on Clostridium spp. occurrence is exerted by factors potentially associated with primary production, like the type of fertilisation and the contamination level of the ensiled feed material. Clostridium spp. was detected in 232 (76\%) samples, and C. perfringens strains, predominantly toxinotype A, in 79 (26\%). C. botulinum occurrence was not detected. Conclusions: Deterioration of silage by clostridia could be prevented by a properly conducted ensiling process with the addition of starter cultures, but the presence of spores mainly depends on primary production and the extent of contamination of the feed material.
\end{abstract}

Keywords: Clostridium botulinum, Clostridium perfringens, Poland, silage, toxins.

\section{Introduction}

Clostridium spp. occurrence in feed material could cause disturbances in the ensiling process leading to deterioration or constitute an epidemiological risk for cattle. Silage as roughage represents the basis of the beef cattle diet. To prepare good quality silage, all the technological procedures in best production practice should be carried out and all principles applied (5). The overarching ensiling principle consists in fast inactivation of enzyme systems and termination of microbial activity.

During harvesting of feed material, the topsoil layer could transfer undesirable microorganisms like bacteria from the Clostridium genus. Some pathogenic members of this genus could colonise the digestive tract of cattle and be shed in excrement, which may contaminate the environment and introduce clostridial pathogens into milk (13). Many experimental data on deterioration of silage by Clostridium spp. and these bacteria's influence on the ensiling process have been reported in literature $(13,18,20,23,25)$. However, the influence of the risk factors which are the hygienic aspects of primary production, the fertilisers used, the storage period of silage, and the intensity of its production is rarely described in literature and is underestimated. Taking into account the epidemiological aspects, pathogenic species like $C$. perfringens and $C$. botulinum are of great importance. $C$. perfringens is one of the most widespread bacteria and ubiquitous in soil, sewage, food, and faeces. C. perfringens is able to produce up to 30 toxins, and its strains are classified into seven categories (A to $\mathrm{G}$ ) according to the combination of the major toxins $\alpha, \beta, 1$, and $\varepsilon$, Clostridium perfringens enterotoxin (CPE), and necrotic enteritis B-like toxin (NetB) they produce (9). Besides the listed major toxins, numerous minor ones can be produced by this microorganism. In animals, the six toxinotypes $\mathrm{A}-\mathrm{F}$ 
cause numerous forms of enteritis and this is associated with enterotoxaemia in cattle. The recently described toxinotype $\mathrm{G}$ is able to produce NetB toxin. It is supposed to play an important role in necrotic enteritis in broiler chickens (6). Dynamic growth of the opportunistic species $C$. perfringens in the small intestine can cause an acute or peracute syndrome with a fatality rate close to $100 \%(6,9)$.

C. botulinum is the microorganism able to produce the most lethal toxins (botulinum neurotoxins - BoNTs) found in the environment. The most frequently seen botulism symptoms in cattle are caused by BoNT/C and $\mathrm{D}$ and their mosaic variants. According to Moeller et al. (14), the median toxic dose $\left(\mathrm{MTD}_{50}\right)$ of BoNT/C for cattle is $0.388 \mathrm{ng} / \mathrm{kg}$ (3.88 mouse lethal doses $/ \mathrm{kg}$ ). This dose suggests that cattle are 12.88 times more sensitive to BoNT/C than mice on a per-kilogram basis. Botulism cases in cattle are very rare, however, they are economically damaging. Most of them are associated with feeding silage contaminated by this microorganism, BoNT/C or D, or their mosaic variants (17).

The aim of this study was evaluation of the occurrence of the Clostridium genus and its pathogenic species $C$. perfringens and $C$. botulinum in silage samples collected from all Polish provinces. The study focused on the potential environmental and technological determinants of the presence of these microorganisms in silage samples.

\section{Material and Methods}

Silage samples. The study was carried out on 305 silage samples which had been collected randomly and directly from farms located in all Polish provinces. Silage was collected during official surveillance of feeding stuffs in Poland carried out in the years 20162017. A total of 207 corn, 75 grass, 13 alfalfa, 2 beet pulp, 2 rye, 2 crushed grain, and 4 shamrock silage samples were gathered and examined (Table 1).

Approximately two thirds $(207 / 305 ; 68 \%)$ of the samples were prepared with starter culture addition (Table 2) and 115/305 (38\%) were prepared from feed material harvested from fields fertilised with manure or slurry (organic fertilisers) (Table 3 ). The storage period of collected samples varied from 1 to 24 months (Table 4). Samples were collected from farms with herd sizes ranging from 12 to 2,300 cows (Table 5).

Culture process. A $10 \mathrm{~g}$ portion of each sample was inoculated in two bottles with $90 \mathrm{~mL}$ of deoxygenated $\left(10 \mathrm{~min} / 100^{\circ} \mathrm{C}\right)$ tryptone peptone glucose yeast extract broth (TPGY; $50 \mathrm{~g} / \mathrm{L}$ of casein enzymic hydrolysate, $5 \mathrm{~g} / \mathrm{L}$ of peptic digest of animal tissue, $20 \mathrm{~g} / \mathrm{L}$ of yeast extract, $4 \mathrm{~g} / \mathrm{L}$ of dextrose, and $1 \mathrm{~g} / \mathrm{L}$ of sodium thioglycolate with a final $\mathrm{pH}$ of $7.0 \pm 0.2$ ) at $25^{\circ} \mathrm{C}$ and one of them was pasteurised at $70^{\circ} \mathrm{C}$ for $15 \mathrm{~min}$. Subsequently, the samples were incubated at $37^{\circ} \mathrm{C}$ for $48 \mathrm{~h}$ under anaerobic conditions. After this time, a few drops of liquid culture were spread onto the surface of Willis-Hobbs agar $(10 \mathrm{~g} / \mathrm{L}$ of peptic digest of animal tissue, $10 \mathrm{~g} / \mathrm{L}$ of meat extract, $5 \mathrm{~g} / \mathrm{L}$ of sodium chloride, $12 \mathrm{~g} / \mathrm{L}$ of lactose, $0.032 \mathrm{~g} / \mathrm{L}$ of neutral red, $12 \mathrm{~mL}$ of egg yolk emulsion, and $10 \mathrm{~g} / \mathrm{L}$ of agar with a final $\mathrm{pH}$ of $7.0 \pm 0.2)$ at $25^{\circ} \mathrm{C}$ and incubated anaerobically at $37^{\circ} \mathrm{C}$ for $48 \mathrm{~h}$. Aerobic control of each sample was provided. Simultaneously, the Clostridium spp. contamination level and $\mathrm{pH}$ value of the silage samples were determined according to the Polish PN-R-64791 (19) and European EN-ISO 7218:2007 (8) standards. The contamination level was expressed as colony-forming units (cfu) per gram of silage in subsequent decimal dilutions of each sample (e.g. $10^{1}, 10^{2}$, and $\left.10^{3} \mathrm{cfu} / \mathrm{g}\right)$.

Table 1. Examined silage samples

\begin{tabular}{|c|c|c|c|c|c|c|c|c|}
\hline \multirow[b]{2}{*}{ Province } & \multicolumn{7}{|c|}{ Silage } & \multirow[b]{2}{*}{$\begin{array}{l}\text { Total in } \\
\text { provinces }\end{array}$} \\
\hline & Corn & Grass & Alfalfa & Beet pulp & Rye & $\begin{array}{l}\text { Crushed } \\
\text { grain }\end{array}$ & Shamrock & \\
\hline Greater Poland & 11 & 4 & 1 & - & 1 & - & - & 17 \\
\hline Holy Cross & 14 & 4 & 3 & - & - & - & - & 21 \\
\hline Kuyavian-Pomeranian & 12 & 3 & 2 & 2 & - & 1 & - & 20 \\
\hline Lesser Poland & 5 & 4 & - & - & - & - & - & 9 \\
\hline Lower Silesian & 10 & 5 & 1 & - & 1 & - & 2 & 19 \\
\hline Lublin & 19 & 1 & - & - & - & - & - & 20 \\
\hline Lubuskie & 12 & 8 & - & - & - & - & 1 & 21 \\
\hline Łódź & 16 & 3 & - & - & - & - & - & 19 \\
\hline Masovian & 18 & 4 & - & - & - & - & - & 22 \\
\hline Opole & 14 & 4 & 2 & - & - & - & - & 20 \\
\hline Podlasie & 16 & 4 & - & - & - & - & - & 20 \\
\hline Pomeranian & 15 & 6 & - & - & - & - & - & 21 \\
\hline Silesian & 17 & 2 & - & - & - & - & - & 19 \\
\hline Subcarpathian & 10 & 7 & 2 & - & - & - & 1 & 20 \\
\hline Warmian-Masurian & 13 & 6 & 1 & - & - & - & - & 20 \\
\hline West Pomeranian & 5 & 10 & 1 & - & - & 1 & - & 17 \\
\hline Total & 207 & 75 & 13 & 2 & 2 & 2 & 4 & 305 \\
\hline
\end{tabular}


Table 2. Silage enriched with starter culture

\begin{tabular}{|c|c|c|c|c|c|c|c|c|}
\hline \multirow[b]{2}{*}{ Province } & \multicolumn{7}{|c|}{ Silage (enriched/total by material) } & \multirow[b]{2}{*}{$\begin{array}{l}\text { Enriched/total in } \\
\text { provinces }(\%)\end{array}$} \\
\hline & Corn & Grass & Alfalfa & Beet pulp & Rye & Crushed grain & Shamrock & \\
\hline Greater Poland & $7 / 11$ & $3 / 4$ & $0 / 1$ & - & $0 / 1$ & - & - & $10 / 17(59)$ \\
\hline Holy Cross & $11 / 14$ & $4 / 4$ & $2 / 3$ & - & - & - & - & $17 / 21(81)$ \\
\hline Kuyavian-Pomeranian & $8 / 12$ & $2 / 3$ & $1 / 2$ & $0 / 2$ & - & $0 / 1$ & - & $11 / 20(55)$ \\
\hline Lesser Poland & $5 / 5$ & $4 / 4$ & - & - & - & - & - & $9 / 9(100)$ \\
\hline Lower Silesian & $6 / 10$ & $2 / 5$ & $0 / 1$ & - & $0 / 1$ & - & $0 / 2$ & $8 / 19(42)$ \\
\hline Lublin & $17 / 19$ & $0 / 1$ & - & - & - & - & - & $17 / 20(85)$ \\
\hline Lubuskie & $9 / 12$ & $6 / 8$ & - & - & - & - & $1 / 1$ & $16 / 21(76)$ \\
\hline Łódź & $12 / 16$ & $1 / 3$ & - & - & - & - & - & $13 / 19(68)$ \\
\hline Masovian & $15 / 18$ & $2 / 4$ & - & - & - & - & - & $17 / 22(77)$ \\
\hline Opole & $12 / 14$ & $0 / 4$ & $1 / 2$ & - & - & - & - & $13 / 20(65)$ \\
\hline Podlaskie & $14 / 16$ & $4 / 4$ & - & - & - & - & - & $18 / 20(90)$ \\
\hline Pomeranian & $11 / 15$ & $3 / 6$ & - & - & - & - & - & $14 / 21(67)$ \\
\hline Silesian & $11 / 17$ & $2 / 2$ & - & - & - & - & - & $13 / 19(68)$ \\
\hline Subcarpathian & $6 / 10$ & $3 / 7$ & $1 / 2$ & - & - & - & $1 / 1$ & $11 / 20(55)$ \\
\hline Warmian-Masurian & $12 / 13$ & $2 / 6$ & $1 / 1$ & - & - & - & - & $15 / 20(75)$ \\
\hline West Pomerania & $2 / 5$ & $2 / 10$ & $0 / 1$ & - & - & $1 / 1$ & - & $5 / 17(29)$ \\
\hline Enriched/total (\%) & $158 / 207(76)$ & $40 / 75(53)$ & $6 / 13(46)$ & $0 / 2(0)$ & $0 / 2(0)$ & $1 / 2(50)$ & $2 / 4(50)$ & $207 / 305(68)$ \\
\hline
\end{tabular}

Table 3. Samples of silage made of material harvested from areas fertilised organically (manure and slurry)

\begin{tabular}{|c|c|c|c|c|c|c|c|c|}
\hline \multirow[b]{2}{*}{ Province } & \multicolumn{7}{|c|}{ Silage (organically fertilised/total by material) } & \multirow[b]{2}{*}{$\begin{array}{l}\text { Organically } \\
\text { fertilised/total in } \\
\text { provinces }(\%)\end{array}$} \\
\hline & Corn & Grass & Alfalfa & Beet pulp & Rye & $\begin{array}{l}\text { Crushed } \\
\text { grain }\end{array}$ & Shamrock & \\
\hline Greater Poland & $5 / 11$ & $1 / 4$ & $1 / 1$ & - & $0 / 1$ & - & - & $7 / 17(41)$ \\
\hline Holy Cross & $5 / 14$ & $2 / 4$ & $2 / 3$ & - & - & - & - & $9 / 21(43)$ \\
\hline Kuyavian-Pomeranian & $5 / 12$ & $2 / 3$ & $1 / 2$ & $0 / 2$ & - & $0 / 1$ & - & $8 / 20(40)$ \\
\hline Lesser Poland & $1 / 5$ & $0 / 4$ & - & - & - & - & - & $1 / 9(11)$ \\
\hline Lower Silesian & $7 / 10$ & $3 / 5$ & $0 / 1$ & - & $0 / 1$ & - & $0 / 2$ & $10 / 19(53)$ \\
\hline Lublin & $10 / 19$ & $0 / 1$ & - & - & - & - & - & $10 / 20(50)$ \\
\hline Lubuskie & $5 / 12$ & $2 / 8$ & - & - & - & - & $0 / 1$ & $7 / 21(33)$ \\
\hline Łódź & $3 / 16$ & $1 / 3$ & - & - & - & - & - & $4 / 19(21)$ \\
\hline Masovian & $5 / 18$ & $0 / 4$ & - & - & - & - & - & $5 / 22(23)$ \\
\hline Opole & $9 / 14$ & $1 / 4$ & $2 / 2$ & & & & & $12 / 20(60)$ \\
\hline Podlaskie & $3 / 16$ & $0 / 4$ & - & - & - & - & - & $3 / 20(15)$ \\
\hline Pomeranian & $7 / 15$ & $3 / 6$ & - & - & - & - & - & $10 / 21(48)$ \\
\hline Silesian & $7 / 17$ & $0 / 2$ & - & - & - & - & - & $7 / 19(37)$ \\
\hline Subcarpathian & $7 / 10$ & $2 / 7$ & $1 / 2$ & - & - & - & $0 / 1$ & $10 / 20(50)$ \\
\hline Warmian-Masurian & $0 / 13$ & $0 / 6$ & $1 / 1$ & - & - & - & - & $1 / 20(5)$ \\
\hline West Pomeranian & $4 / 5$ & $5 / 10$ & $1 / 1$ & - & - & $1 / 1$ & - & $11 / 17(65)$ \\
\hline Organically fertilised/total (\%) & $83 / 207(40)$ & $22 / 75(29)$ & $9 / 13(69)$ & $0 / 2$ & $0 / 2$ & $1 / 2(50)$ & $0 / 4$ & $115 / 305(38 \%)$ \\
\hline
\end{tabular}

Table 4. Storage periods of collected silage

\begin{tabular}{ll}
\hline Number of silage samples & Storage period (months) \\
\hline $109(36 \%)$ & $1-4$ \\
\hline $100(33 \%)$ & $5-8$ \\
\hline $81(27 \%)$ & $9-12$ \\
\hline $15(5 \%)$ & $13-24$ \\
\hline
\end{tabular}

Table 5. Silage samples collected from farms by herd size

\begin{tabular}{|c|c|c|c|c|c|c|c|}
\hline \multirow{2}{*}{ Province } & \multicolumn{7}{|c|}{ Herd size } \\
\hline & $<50$ & $<100$ & $<250$ & $<500$ & $<1,000$ & $<2,000$ & $<2,500$ \\
\hline Greater Poland & 3 & 4 & 2 & 6 & - & 1 & 1 \\
\hline Holy Cross & 10 & 6 & 4 & 1 & - & - & - \\
\hline Kuyavian-Pomeranian & 3 & 8 & 2 & 3 & 4 & - & - \\
\hline Lesser Poland & 6 & - & 3 & - & - & - & - \\
\hline Lower Silesian & 3 & 2 & 3 & 5 & 2 & 4 & - \\
\hline Lublin & 8 & 4 & 7 & & 1 & - & - \\
\hline Lubuskie & 4 & 3 & 9 & 3 & - & 1 & 1 \\
\hline Łódź & 11 & 6 & 1 & - & 1 & - & - \\
\hline Masovian & 11 & 6 & 4 & 1 & - & - & - \\
\hline Opole & 4 & & 4 & 5 & 4 & 2 & 1 \\
\hline Podlaskie & 5 & 12 & 3 & - & - & - & - \\
\hline Pomeranian & 6 & 2 & 4 & 7 & 2 & - & - \\
\hline Silesian & 8 & 8 & 1 & 1 & 1 & - & - \\
\hline Subcarpathian & 7 & 7 & 4 & 1 & 1 & - & - \\
\hline Warmian-Masurian & 5 & 8 & 4 & 3 & - & - & - \\
\hline West Pomeranian & 1 & 4 & 3 & 6 & 3 & - & - \\
\hline Total & 95 & 80 & 58 & 42 & 19 & 8 & 3 \\
\hline
\end{tabular}


The occurrence of Clostridium spp. was proved by morphological evaluation of growth and Gram staining. Characteristic colonies with lipolytic properties (a pearl layer) were subjected to further analysis using a realtime PCR method for $C$. botulinum ntnh gene detection. Protuberant yellow colonies with smooth surfaces surrounded by a lecithinolytic layer were subjected to multiplex PCR (mPCR) analysis for $C$. perfringens detection and toxinotype determination.

DNA preparation for Clostridium botulinum detection. The DNA for $C$. botulinum detection was extracted from $1 \mathrm{~mL}$ of liquid culture in TPGY broth and from suspected lipolytic colonies grown on WillisHobbs agar plates. DNA was isolated and purified using a GenomicMini AX Bacteria kit (A\&A Biotechnology, Poland), according to the manufacturer's instructions. The amount of DNA used in the PCR reaction varied between 1 and $25 \mathrm{ng}$.

DNA preparation for Clostridium perfringens detection. The DNA of strains suspected of being C. perfringens was extracted from characteristic colonies grown on Willis-Hobbs agar according to the method described by Kukier and Kwiatek (10). To perform a reliable multiplex PCR with a heat-lysed bacterial suspension, material from an overnight culture of suspected isolates on Willis-Hobbs agar was resuspended with a plastic disposable inoculating loop in $2 \mathrm{~mL}$ of PBS to obtain a $3.5 \mathrm{McF}$ arland turbidity, and then bacterial suspensions were incubated in $1.5 \mathrm{~mL}$ disposable Eppendorf tubes at $95^{\circ} \mathrm{C}$ for $15 \mathrm{~min}$. Next, the tubes were subjected to heat lysis at $95^{\circ} \mathrm{C}$ for $15 \mathrm{~min}$ and after that were placed on ice for $5 \mathrm{~min}$ and centrifuged at $11,000 \times \mathrm{g}$ for $8 \mathrm{~min}$.

PCR methods for Clostridium perfringens detection. The isolates were examined for the presence of cpa ( $\alpha$ toxin), cpb ( $\beta)$, cpb2 ( $\beta 2)$, etx ( $(\varepsilon)$, iap (1), and cpe (enterotoxin) toxin genes by $\mathrm{mPCR}$ according to the method by Baums et al. (1). The reaction was performed according to Kukier and Kwiatek's procedure (10) in a volume of $50 \mu \mathrm{L}$ with $2.5 \mathrm{mM}$ of $\mathrm{MgCl}_{2}, 0.25 \mathrm{mmol}$ of each deoxyribonucleotide triphosphate, and $2.5 \mathrm{U}$ of Taq polymerase (Thermo Fisher Scientific, USA) as reagents and with the primers used by Baums et al. (1).

Real-time PCR method for $C$. botulinum detection. A set of seven primers and a TaqMan probe accredited to Raphael and Andreadis (21) were used for detection of the $n t n h$ gene common to all C. botulinum toxinotypes. The reactions were conducted with reagents comprising $5 \mu \mathrm{L}$ of DNA, $4 \mu \mathrm{L}$ of LightCycler TaqMan Master (Roche Diagnostics, Germany), 0.7 $\mu \mathrm{M}$ of each primer, and $0.24 \mu \mathrm{M}$ of TaqMan probe. The real-time PCR was performed using a LightCycler 2.0 thermocycler (Roche, Switzerland).

Statistical tests. The relationships and statistical significance were investigated between the contamination level of Clostridium spp. and the following factors: $\mathrm{pH}$ value, addition of starter culture, organic fertilisation, storage period of silage, herd size, and $C$. perfringens occurrence. The same were also investigated between C. perfringens occurrence and $\mathrm{pH}$ of silage The $\chi^{2}$ test average values were compared to those of continuous and non-continuous Student's $t$-tests. All significant results were validated by their $\mathrm{P}$ value of $<0.05$, and tendency (close-to-significant results) was validated by its $\mathrm{P}$ value $\varepsilon(0.051,0.1)$. All statistical analyses were conducted with Statistica 13.1 software (Tibco, USA).

\section{Results}

Clostridium spp. occurrence. Clostridium spp. was detected in $232(76 \%)$ examined samples and occurrence of this genus was observable at least at the level of $10^{1} \mathrm{cfu} / \mathrm{g}$ in each positive silage sample. The contamination level ranged from $10^{1} \mathrm{cfu} / \mathrm{g}$ to $10^{4} \mathrm{cfu} / \mathrm{g}$ and in most of the samples was $10^{1} \mathrm{cfu} / \mathrm{g}(31 \%)$ or $10^{2} \mathrm{cfu} / \mathrm{g}(27 \%)$. A higher level of $10^{3} \mathrm{cfu} / \mathrm{g}$ was found in $12 \%$ and the highest of $10^{4}$ in $6 \%$ of samples (Table 6 ). The highest number of Clostridium spp. positive samples was noted among corn silage samples (157/305) which constituted about $50.5 \%$ of all examined samples.

Clostridium perfringens occurrence. $C$. perfringens strains were isolated from $26 \%(79 / 305)$ of samples. Among them, isolates of toxinotype A able to produce $\alpha$ toxin were detected in 42 samples and the same type of isolates with genes determining the production of $\alpha$ and $\beta 2$ toxins were detected in 33 samples. The strains isolated from two samples showed the presence of genes for $\alpha, \varepsilon$, and $\beta 2$ toxins and were classified to toxinotype D. One sample showed the presence of type E possessing the $\alpha, 1$, and $\beta 2$ toxin genes. Enterotoxic $C$. perfringens was not detected. The highest number of $C$. perfringenspositive isolates was noted in corn silage samples $(51 / 305)$ which constituted about $17 \%$ of the total tested.

Table 6. Contamination level by Clostridium spp.

\begin{tabular}{|c|c|c|c|c|c|}
\hline \multirow[t]{2}{*}{ Number of silage samples } & \multicolumn{4}{|c|}{ Level } & \multirow[b]{2}{*}{ Total $(\%)$} \\
\hline & $10^{1} \mathrm{cfu} / \mathrm{g}$ & $10^{2} \mathrm{cfu} / \mathrm{g}$ & $10^{3} \mathrm{cfu} / \mathrm{g}$ & $10^{4} \mathrm{cfu} / \mathrm{g}$ & \\
\hline Corn & 71 & 56 & 23 & 7 & $157 / 207(76)$ \\
\hline Grass & 22 & 18 & 11 & 9 & $60 / 75(80)$ \\
\hline Alfalfa & - & 2 & 2 & 3 & $7 / 13(54)$ \\
\hline Beet pulp & - & 1 & - & - & $1 / 2(50)$ \\
\hline Rye & - & 1 & - & - & $1 / 2(50)$ \\
\hline Crushed grain & 1 & 1 & - & - & $2 / 2(100)$ \\
\hline Shamrock & 1 & 3 & - & - & $4 / 4(100)$ \\
\hline Total $(\%)$ & $95 / 305(31)$ & $82 / 305(27)$ & $36 / 305(12)$ & $19 / 305(6)$ & $232 / 305(76)$ \\
\hline
\end{tabular}


Table 7. $\mathrm{pH}$ values of examined silages samples

\begin{tabular}{|c|c|c|c|c|c|}
\hline \multirow{2}{*}{ Silage } & \multicolumn{5}{|c|}{$\mathrm{pH}$} \\
\hline & $3.50-3.99$ & $4.00-4.49$ & $4.50-4.99$ & $5.00-5.99$ & $6.0-7.99$ \\
\hline Corn & 74 & 98 & 7 & 8 & 1 \\
\hline Grass & 3 & 13 & 19 & 30 & 8 \\
\hline Alfalfa & & 3 & 3 & 4 & 2 \\
\hline Beet pulp & 1 & 1 & & - & - \\
\hline Rye & - & 1 & 1 & - & - \\
\hline Crushed grain & - & 1 & - & - & 1 \\
\hline Shamrock & - & - & - & 3 & - \\
\hline Total (\%) & $78 / 282(28)$ & $117 / 282(41)$ & $30 / 282(11)$ & $45 / 282(16)$ & $12 / 282(4)$ \\
\hline
\end{tabular}

Table 8. Statistical significance and tendency of factors determining Clostridium spp. occurrence

\begin{tabular}{lll}
\hline Relationship & Tendency (P value) & Significance (P value) \\
\hline $\begin{array}{l}\left.\text { Clostridium spp. (level } 10^{3} \text { and } 10^{4} \mathrm{cfu} / \mathrm{g}\right) \text { vs } \mathrm{pH} \\
>4.5\end{array}$ & - & 0.007 \\
\hline Clostridium spp. vs organic fertilisation & - & 0.0024 \\
\hline $\begin{array}{l}\left.\text { Clostridium } \text { spp. (level } 10^{3} \mathrm{cfu} / \mathrm{g}\right) \text { vs herd size } \\
(12-800 \text { cows) }\end{array}$ & 0.019 & - \\
\hline
\end{tabular}

Clostridium botulinum occurrence. No C. botulinum $n t n h$ genes were detected in any examined samples.

Acidity of examined silages. The observed $\mathrm{pH}$ value varied from 3.50 to 7.99 . Considerably more samples showed $\mathrm{pH}$ in the range of $4.00-4.49(41 \%)$ than in other ranges. The majority of corn silage samples had $\mathrm{pH}$ from 3.50 to 4.49 , whilst most grass silage samples ranged from 4.00 to 5.99 (Table 7).

Statistical analysis results. Statistical analysis showed significance in the correlation between $\mathrm{pH}>4.5$ and Clostridium spp. contamination level of $10^{4} \mathrm{cfu} / \mathrm{g}$ $(\mathrm{P}=0.007)$. No significant correlation between the other contamination levels and $\mathrm{pH}$ values was found.

A statistical tendency close to significance was noted in the relationship between starter culture omission and Clostridium spp. contamination levels of $10^{3}$ and $10^{4} \mathrm{cfu} / \mathrm{g}(\mathrm{P}=0.095)$. Significance also emerged in the relationship between Clostridium spp. occurrence and organic fertilisation $(\mathrm{P}=0.0024)$, but no statistical significance or tendency was discerned when Clostridium spp. occurrence and the storage period of silage were compared. Significant was the relationship between the relatively high contamination level of $10^{3} \mathrm{cfu} / \mathrm{g}$ and herd head counts from 12 to over 800 $(\mathrm{P}=0.019)$ (Table 8). Statistical significance was not observed in the relationship between feed material used for silage production and Clostridium spp. occurrence.

\section{Discussion}

The results of this study indicated that Clostridium spp. was present in $76 \%$ of silage samples, in most cases at $10^{1}$ and $10^{2} \mathrm{cfu} / \mathrm{g}$. According to Rammer et al. (20), in a freshly harvested crop the minimum level of spores determined did not usually exceed 100/g. It was observed that the storage period had no statistically significant influence on Clostridium spp. occurrence in silage samples and this fact could be explained by high contamination of the feed material used to produce it. Primary production could account for most of the presence of clostridia in the examined samples.
Tabacco et al. (25) found that after a properly executed ensiling process using a Lactobacillus buchneri starter culture, the clostridia spore count did not increase in maize silage after $342 \mathrm{~h}$ of incubation. The same authors also observed that use of a Lactobacillus plantarum starter culture also had an inhibitory effect on clostridia growth, limiting the increase in the number of spores to a minimum. Our results showed only one correlation between starter culture omission and high contamination levels of $10^{3}$ and $10^{4} \mathrm{cfu} / \mathrm{g}(\mathrm{P}=0.095)$. It could be concluded that starter culture addition might inhibit the growth of Clostridium spp.; however, the microbiological condition of feed material exerts the most significant influence on the silage occurrence of this species.

The highest contamination by Clostridium spp. was revealed in the samples with $\mathrm{pH}$ between 4 and 5 (most of the examined samples), which is considered the optimal $\mathrm{pH}$ for good quality silage. Severe deterioration by clostridia is observed in silage with $\mathrm{pH}$ above 7.0. This $\mathrm{pH}$ was recorded only in an insignificant number of examined samples. An interesting finding is the high contamination with Clostridium spp. in the samples with $\mathrm{pH}$ between 3.5 and 3.99. It could be explained by a high influence of anaerobic microflora transferred to silage from primary production processes. Low $\mathrm{pH}$ could have a fixative effect for Clostridium spp. spores derived from feed material (13). Statistical significance between high contamination with Clostridium spp. of $10^{4} \mathrm{cfu} / \mathrm{g}$ and $\mathrm{pH}>5$ was noticed. It indicated possible deterioration of silage if the contamination level is high and $\mathrm{pH}$ favourable to clostridia growth. Cai et al. (3) reported that if silage $\mathrm{pH}$ does not decline to $<4.0$, the growth of coliform and aerobic bacteria is not inhibited. Below this $\mathrm{pH}$, growth of pathogenic microflora is inhibited, however, spores of Clostridium spp. are still likely to occur. Statistical significance was observed in the relationship between organic fertilisation with slurry or manure and Clostridium spp. occurrence. Instances of clostridia in silage are principally considered to be connected with contamination from soil and farmyard manure $(18,20)$. However, in a properly conducted ensiling process maintaining low $\mathrm{pH}$, their significance 
is limited, because of the inhibitory $\mathrm{pH}$ level and activity of lactic acid microflora. No statistically significant relationship between Clostridium spp. occurrence and type of silage (corn or grass) was discovered. Statistical analysis showed significance between relatively high contamination with Clostridium spp. of $10^{3}$ spores/g and herd size ranging from 12 to 800 cows. It is difficult to interpret if occurrence of clostridia is determined by the intensity of dairy or beef production; however, on the bigger farms (with herd sizes over approximately 1,000 cows), hygienic practices attain a far higher standard and different equipment is used.

C. perfringens strain occurrence was found in 79 (26\%) examined samples. Mainly type A strains were isolated, and among them $33(11 \%)$ were able to produce $\beta 2$ toxin. Toxinotype D and E occurrence was noticed only in three silage samples. The infective dose of $C$. perfringens for cattle is undetermined. The occurrence of $C$. perfringens type $\mathrm{A}$ in the digestive tract of cattle is physiological, but its pathogenesis depends on physiological conditions. C. perfringens type A has been associated with several diseases in cattle, such as clostridial enteritis in neonates, haemorrhagic abomasitis or abomasal ulceration in affected calves, haemorrhagic enteritis in adult cattle and calves, or type A haemorrhagic enteritis and sudden death in veal calves during the suckling period $(6,12)$. Some $C$. perfringens type A isolates with the ability to produce $\beta 2$ toxin could cause haemorrhagic lesions in the small intestine in cases of bovine enterotoxaemia (along with $\alpha$ toxin). Isolates of C. perfringens type A have also been suggested as a cause of jejunal haemorrhage syndrome (JHS) in beef and dairy cattle. However, further experiments attempting to reproduce JHS using this microorganism did not prove the theory thoroughly, suggesting the possibility of other contributing or predisposing factors in the aetiology of this disease $(4,6)$.

C. perfringens type A strains are natural inhabitants of normal intestinal microbiota, and isolation is not sufficient for proper diagnosis. It is very difficult to clearly associate the presence of this toxinotype with disease. Also, the major $\alpha$ toxin can be detectable in the faeces of healthy animals and has little diagnostic value (6). We also found toxinotypes D and E, which, in contrast, can be mooted as causative disease agents in animals. $C$. perfringens type $\mathrm{E}$ is considered an infrequent cause of haemorrhagic enteritis and sudden death in neonatal calves (17); however, one report also describes type E enterotoxaemia in adult cows (22). Literature reports are mainly focused on the type D strain pathology. C. perfringens types A and D are both often described as enterotoxaemia causative agents, however, they show completely different pathologies (6). Various diseases caused by $C$. perfringens are determined as enterotoxaemia, however, this term should only be used for symptoms mainly associated with systemic actions of the toxins. Characteristic for type D enterotoxaemia is the occurrence of neurological signs without the major intestinal lesions, in contrast to the disease caused by type A strains, where the characteristic symptoms are intestinal haemorrhages and necrosis and neurological effects are only sporadic $(6,15)$.

C. botulinum occurrence was not evident and none of the examined samples was associated with a botulism case in cattle. C. botulinum comprises microorganisms which are characterised by huge genetic variability, especially those classified to group III, which causes most of the botulism outbreaks in cattle. Outbreaks were associated with the use of poultry litter as a dietary supplement and ingestion of silage and water contaminated by carcasses of small ruminants or birds. It is nevertheless quite improbable that this could occur on properly managed farms. Botulism cases were linked to feeding with insufficiently acidified silage contaminated with $C$. botulinum from soil, or ingestion of silage made from polluted brewers' grain. In the last few decades, an increasing number of $\mathrm{D}$ - and mosaic D/C-type botulism outbreaks associated with direct contact with poultry litter have been reported, caused by spores of type $\mathrm{D}$ or $\mathrm{D} / \mathrm{C}$ (which possess genes coding for two-thirds of the type D toxin and one-third of the type C toxin). It is worth considering the hypothesis that C. botulinum of these types could have been present in the litter due to asymptomatic carriage in the poultry gut, as has been observed with $C$. botulinum type B and $\mathrm{C}$ in pigs (16). Particles of litter containing the spores or the BoNTs could then be dispersed in the silage pasture by wind, runoff water or scavengers. Poultry is less susceptible than cattle to type D botulism $(7,11)$ and the mosaic D/C form. Further research on the asymptomatic carriage of type $\mathrm{D}$ and $\mathrm{D} / \mathrm{C} C$. botulinum by poultry is needed in order to understand the risk of exposure of cattle to $C$. botulinum spores associated with poultry litter. Therefore it is reasonable to recommend that farmers ensure the safe storage and proper disposal of poultry and ruminant litter in order to prevent further cattle botulism outbreaks (22).

The majority of these cases were attributed to the ingestion of BoNTs from poultry or mammal carcasses or litter when the material was used as fertiliser or stacked on pastures, although this association was not always proved (23). In the last decade, some reports were published of botulism cases in cattle associated with biogas plant waste and digestants $(2,24)$.

The high genetic variability of $C$. botulinum group III, loss of toxinogenic abilities and problems with cultivation of this microorganism make laboratory diagnosis of this disease extremely difficult. In our experiments we used the methods enabling the detection of this microorganism directly from liquid culture, which increased the chance of detection of this microorganism before potential toxinogenicity was lost. However, samples showed too few $C$. botulinum spores for these to be a probably causative agent of botulism in herds fed the silage examined. We do not have information about any usage of poultry manure or biogas plant digestants as fertilisers. 
Summarising, the conducted statistical analysis shows that the most influential effect on Clostridium spp. occurrence is felt from factors potentially associated with primary production like fertilisation and the contamination level of feed material used for silage preparation. Deterioration of silage by clostridia could be stopped by a properly conducted ensiling process with addition of starter cultures; however, the presence of spores is highly probable and could pose a biological threat to animals.

Conflict of Interests Statement: The authors declare that there is no conflict of interests regarding the publication of this article.

Financial Disclosure Statement: This study was financed by the statutory activity of the National Veterinary Research Institute in Puławy.

Animal Rights Statement: Not applicable.

\section{References}

1. Baums C.G., Schotte U., Amtsberg G., Goethe R.: Diagnostic multiplex PCR for toxin genotyping of Clostridium perfringens isolates. Vet Microbiol 2004, 100, 11-16.

2. Böhnel H., Schwagerick B., Gessler F.: Visceral botulism - a new form of bovine Clostridium botulinum toxication. J Vet Med A 2001, 48, 373-383

3. Cai Y., Benno Y., Ogawa M., Ohamomo S., Kumai S., Nakase T.: Influence of Lactobacillus spp. from an inoculant and of Weissella and Leuconostoc spp. from forage crops on silage fermentation. Appl Environ Microbiol 1998, 64, 2982-2987.

4. Deprez P.: Clostridium perfringens infections - a diagnostic challenge. Vet Rec 2015, 177, 388-389.

5. Doležal P., Pyrochta V., Doležal J.: Effects of chemical preservative and pressing of ensiled sugar-beet pulp on the quality of fermentation process. Czech J Anim Sci 2005, 50, 553-560.

6. Goossens E., Valgaeren B.R., Pardon B., Haesebrouck F., Ducatelle R., Deprez P.R., Van Immerseel F.: Rethinking the role of alpha toxin in Clostridium perfringens-associated enteric diseases: a review on bovine necro-haemorrhagic enteritis. Vet Res 2017, 48, 1-17, doi: 10.1186/s13567-017-0413-x.

7. Gross W.B., Smith L.D.: Experimental botulism in gallinaceous birds. Avian Diseases 1971, 15, 716-722.

8. International Organization for Standardization Technical Committee ISO/TC 34/SC9 Microbiology: ISO 7218:2007 Microbiology of food and animal feeding stuffs - General requirements and guidance for microbiological examinations. International Organization for Standardization, Geneva, 2014.

9. Kiu R., Hall L.J.: An update on the human and animal enteric pathogen Clostridium perfringens. Emerg Microbes Infect 2018, 7, 1-15, doi: 10.1038/s41426-018-0144-8.

10. Kukier E., Kwiatek K.: Phenotypical and genotypical characterisation of Clostridium perfringens strains isolated from feedingstuffs. Bull Vet Inst Pulawy 2010, 54, 501-511.
11. Le Maréchal C., Woudstra C., Fach P.: Botulism. In: Clostridial Diseases of Animals, edited by F.A. Uzal, J.G. Songer, J.F. Prescott, M.R. Popoff, John Wiley \& Sons, Inc. Hoboken, 2016, pp. 303-330.

12. Lebrun M., Mainil J.G., Linden A.: Cattle enterotoxaemia and Clostridium perfringens: description, diagnosis, and prophylaxis. Vet Rec 2010, 167, 13-22.

13. Mlejnková V., Fröhdeová M., Kalhotka L., Doležal P.: Microbiological quality of experimental silages in combination with the addition of topsoil soil layer and ensiling additives. Acta Univ Agric Silvic Mendel Brun 2014, 62, 1041-1048.

14. Moeller R.B. Jr., Puschner B., Walker R.L., Rocke T., Galey F.D., Cullor J.S., Ardans A.A.: Determination of the median toxic dose of type $C$. botulinum toxin in lactating dairy cows. J Vet Diagn Invest 2003, 15, 523-526.

15. Muylaert A., Lebrun M., Duprez J.N., Labrozzo S., Theys H., Taminiau B., Mainil J.: Enterotoxaemia-like syndrome and Clostridium perfringens in veal calves. Vet Rec 2010, 167, 64-65.

16. Myllykoski J., Nevas M., Lindström M., Korkeala H.: The detection and prevalence of Clostridium botulinum in pig intestinal samples. Int J Food Microbiol 2006, 110, 172-177.

17. Nakamura K., Kohda T., Umeda K., Yamamoto H., Mukamoto M., Kozaki S.: Characterization of the D/C mosaic neurotoxin produced by Clostridium botulinum associated with bovine botulism in Japan. Vet Microbiol 2010, 140, 147-154.

18. Ostling C.E., Lindgren S.E.: Bacteria in manure and on manured and NPK-fertilised silage crops. J Sci Food Agr 1991, 55, 579-588.

19. Polish Committee for Standardization: Polish Standard: PN - R 64791:1994. Animal feeding stuffs - Requirements and microbiological examinations. Polish Committee for Standardization, Warsaw, 1994.

20. Rammer C., Ostling L., Lingvall P., Lindgren S.: Ensiling of manured crops-effect on fermentation. Grass Forage Sci 1994, 49, 343-351.

21. Raphael B.H., Andreadis J.D.: Real-time PCR detection of the nontoxic nonhemagglutinin gene as a rapid screening method for bacterial isolates harboring the botulinum neurotoxin $(A-G)$ gene complex. J Microbiol Methods 2007, 71, 343-346.

22. Redondo L.M., Farber M., Venzano A., Jost B.H., Parma Y.R., Fernandez-Miyakawa M.E.: Sudden death syndrome in adult cows associated with Clostridium perfringens type E. Anaerobe 2013, 20, 1-4.

23. Relun A., Dorso L., Douart A., Chartier C., Guatteo R., Mazuet C., Popoff M.R., Assié S.: A large outbreak of bovine botulism possibly linked to a massive contamination of grass silage by type $\mathrm{D} / \mathrm{C}$ Clostridium botulinum spores on a farm with dairy and poultry operations. Epidemiol Infect 2017, 145, 3477-3485.

24. Seyboldt C., Discher S., Jordan E., Neubauer H., Jensen K.C., Campe A., Kreienbrock L., Scheu T., Wichern A., Gundling F., DoDuc P., Fohler S., Abdulmawjood A., Klein G., Hoedemaker M.: Occurrence of Clostridium botulinum neurotoxin in chronic disease of dairy cows. Vet Microbiol 2015, 177, 398-402.

25. Tabacco E., Piano S., Cavallarin L., Bernardes T.F., Borreani G.: Clostridia spore formation during aerobic deterioration of maize and sorghum silages as influenced by Lactobacillus buchneri and Lactobacillus plantarum inoculants. J Appl Microbiol 2009, 107, 1632-1641. 